\title{
Könyvszemle
}

SIPOS JÚLIA GONDOZÁSÁBAN

\section{NEMZET ÉS MIGRÁCIÓ}

Csepeli György és Örkény Antal a hazai szociálpszichológia vezető kutatói korábban közreadott nemzeti identitással foglalkozó kutatásaikat újabb kötetükben különösen gazdag nemzetközi összehasonlításban helyezik el, s eddigi kutatásaikat még aktuálisabbá tették a migráció problémájának a központba állításával.

A mü igen gazdag empirikus bázisra épül. Az International Social Survey Program három időpontban, 1995-ben, 2003-ban és 2013-ban számos európai országon kívül még Oroszországban és Törökországban is gyüjtött adatait elemzi, majd ezt követi egy 2008-ban más módszerekkel készült felmérés - GFE alapján készült beszámoló az idegenekkel szembeni attitüdökröl. Ezt a migráció nemzetközi változásával foglalkozó rész követi, majd a szerzők hat különböző migránscsoport hazai integrációs esélyeit mérlegelik.

Ez a rendkívül gazdag adatbázis az általam a kérdésben ismert irodalomnál árnyaltabb képet nyújt e sokrétü - nemzet, etnicitás, idegenekkel szembeni attitüdök, vándorlás, integráció - jelenségröl.

Tény ugyanakkor, hogy ennek a kis könyvnek tárgyi és empirikus gazdagsága próbára teszi az olvasókat, olyan könyv ez, amit nem könnyü gyorsolvasással végiglapozni. Gyakran fejtörést okoz az olvasónak, hogy a különböző adatbázisok mennyiben hasonlíthatók össze. A mü célja azonban nem a szórakoztatás, hanem a gondolatébresztés, s ezt a célt Csepeli és Örkény el is érik, igencsak eredményesen.

Rohamosan változó világunkban nem lehet elvárni a szerzőktől, hogy az Európát ért 2015-ös sokk hatását mérni tudják, de meglepő módon már a 2013-as, sőt a 2008-as adatok is egészen jól jelzik, miként válaszolnak majd a különböző európai országok a 2015-ben a kontinensre érkező egymillió menekültre/bevándorlóra.

A könyv szellemiségének fő inspirátora Szücs Jenő Európa három régiójáról írt nagyszerü esszéje. Csepeli és Örkény meggyőző és jól működő módosítást hajt végre Szücs elméletében: három helyett hat régió szerint elemzik az adataikat. A „Nyugatot” négy régióra bontják: az EU központi országai, Dél-Európa, Észak-Európa, illetve a kontinensen kívüli Európa, vagyis Anglia és Írország. Amint az várható volt, Észak-Európa a leginkább befogadó (főleg persze Svéd- 
ország), s a leginkább „modern” Anglia viszont több szempontból éppenséggel „Közép-Európához” hasonlít.

Szücs elméletével összhangban az adatok alátámasztják a nyugatról keletre haladó „lejtő” hipotézisét. A második fejezet nagy eredménye viszont, hogy a nemzeti tudat erőssége nem túlságosan különbözik a különböző régiókban. Közép-Európa hasonló a Nyugathoz, sőt 1995 és 2013 között mintha a két régió közötti távolság csökkent volna. Igaz, ez nem minden szempontból történt így. Amikor a kutatók arról faggatták a válaszadókat, miért büszkék a nemzeti hovatartozásukra akkor bizony a nyugat-keleti lejtő továbbra is meredek. Nyugaton inkább modernizációs értékekre büszkék a válaszadók, a közép-európaiak viszont inkább a oroszokhoz és törökhöz hasonlóan gyakran tradicionális értékekkel hivalkodnak.

A „másokkal” szembeni előítéletek kérdésében tanulságos, hogy minél kisebb a bevándorló népesség annál nagyobb a velük szembeni elöítélet. A 2013-ból vagy korábbról származó adatok fényében nem meglepő, hogy Németország vagy Svédország számottevő EU-n kívüli és muszlim bevándorlás mellett is sokkal befogadóbb volt - s máig az maradt -, mint az etnikai értelemben szinte homogén Magyarország vagy Lengyelország.

A különböző, Magyarországra érkezett bevándorló csoportok integrációjával kapcsolatban a szerzők optimista beszámolót adnak. A legérdekesebb, hogy kiemelkedően a legiskolázottabb csoportot az arabok jelentik (78 százalékuknak van felsőfokú iskolai végzettsége). A legtöbb bevándorló hajlamos a magyar állampolgárságot kérni (feltéve, ha ezért az eredeti állampolgárságukról nem kell lemondaniuk).

A Nemzet és migráció sok szempontból úttörö könyv. A szerzők okkal állapítják meg, hogy a nemzeti identitás szociálpszichológiai mérése viszonylag új keletủ kutatási ág, bár azzal nem értenék egyet, hogy a nemzet kérdése ne lett volna a szociológia által már nagyon korán megfogalmazott probléma. A klasszikus szociológiában nemcsak a nemzet/etnikum kérdése kapott nagy figyelmet, de ebben a kérdésben ütköző két nagy paradigma is korán megfogalmazódott. William Graham Sumner a Folkways címü gigantikus kutatási sorozatában a szociáldarwinizmus hatására a „népek” „esszenciális” fogalmával dolgozott, míg Max Weber ebben a kérdésben is egy korai „konstruktivista” megközelítést nyújtott. Weber szerint a nemzetet a „vélt” közös származás és a „vélt” közös kultúra alkotja.

Van egy másik kritikai megjegyzésem is. A könyv szinte kritika nélkül fogadja el Samuel P. Huntington „civilizációk ütközése” elméletét s föleg azt a tételt, amelyben egyébként Weber is egyetértett Huntingtonnal, hogy az iszlám és a modernitás összeegyeztethetetlen. Bár Weber nyomán sokáig állt az a feltevés, hogy a konfucianizmus a kapitalizmussal összeegyeztethetetlen, egészen addig, amíg a japán gazdasági csoda nyomán nem fordult ellentétébe az érvelés: Shmuel Noah 
Eisenstadt szerint a konfuciánus japánok (és tegyük hozzá: a kínaiak) épp olyan sikeresek az üzletben, mint a keresztények vagy zsidók. A fejlett/modern Nyugat és az elmaradott, tradicionális Kelet modernizációelméleti víziója pontatlan. Minden modern világnézet, civilizáció, vallás ('́gy az iszlám is) tud alkalmazkodni a modernitáshoz. A probléma nem civilizációkban vagy vallásokban, hanem a fundamentalizmusokban van, legyen az a fundamentalizmus keresztény, zsidó, muzulmán vagy marxista-leninista.

Időszerü és tanulságos könyv, ajánlott olvasmány nemcsak társadalomtudósoknak hanem a nemzeti identitás és migráció iránt érdeklődő minden gondolkodó embernek.

(Csepeli György - Örkény Antal: Nemzet és migráció. [e-tankönyv] Budapest: ELTE Társadalomtudományi Kar, 2017)

Szelényi Iván

szociológus, az MTA rendes tagja 


\section{A MAGYAR NYELVTÖRTÉNET KÉZIKÖNYVE}

Tizenöt éve, 2003-ban jelent meg e kötet elözménye, amelyet akkor a szerkesztők és a szerzők egyetemi tankönyvnek szántak (Magyar nyelvtörténet). Ez a könyv a mostanihoz képest mintegy kétszeres terjedelmü, hiszen olyan szaktudományi részletezése nyelvünk történetének, amely a nyelv történetével megismerkedni kívánók szélesebb körének bizonyos felkészültség nélkül nehézséget okozhat. A jelen kötet a tudományosság színvonalából nem engedve nem csupán a felsőoktatásban használható, hanem a magyar nyelvtörténet iránt érdeklődő, szélesebb olvasói körre számítva készült. Minderre biztosíték a két szerkesztő és a tizenhárom szerző szakmai rangja a magyar nyelvtörténeti kutatásokban.

A kötet egésze az előzményéhez képest azt is mutatja, hogy a 20. század utolsó évtizedei óta változások vannak a magyar nyelvtörténeti vizsgálatokban. A strukturalista (generatív) alapú kutatások, a társadalom nyelvhasználatának különböző jelenségei (vagyis pragmatikai vizsgálatok) mellett az ómagyar kor nyelvi állapotának korábban oly nagy részletességü leírása mellé a középmagyar koré kap egyre nagyobb teret. Ezzel együtt jár, hogy nem csupán egyházi jellegü írásbeliség, hanem világi iratanyag is szerepel forrásként az újabb nézőpontú elemzésekben.

A kézikönyv öt fejezetre oszlik, amelyeket a mellékletek egészítenek ki. Ezekben a szakszavak szótára, a források, a bibliográfia, a tárgymutató, valamint szemléltető hasonmások és térképek találhatók. A bibliográfiai rész (476-505.) terjedelme is jelzi a széles körü áttekintést, amely abban is megnyilvánul, hogy megtalálható a legfrissebb szakirodalom, és abban is, hogy a nem kimondottan nyelvtudományi részekben különböző szakmák képviselőinek müvei is ott vannak. A szakszavak szótára (419-459.) ugyancsak fontos része a könyvnek, a szakkifejezések ismerete és egységes értelmezése nyilvánvaló módon fontos a szakmabeli és az érdeklődő olvasó számára.

A bevezető fejezet a nyelv, a nyelvi változás és a történeti nyelvvizsgálat mibenlétéről ad eligazítást. Ezt követi a Magyar nyelvtörténet mint kutatási tárgy című nagyfejezet. Ebben a magyar nyelvtörténet korszakai vannak tárgyalva. A korszakolás egyik kérdése, hogy mióta beszélhetünk önálló magyar nyelvről. A különböző nyelvészeti, régészeti, történészi vélemények taglalása után Kr. e. 1000 vagy 1500 körülire tehető az ősmagyar kor, amely a magyar honfoglalásig tart. Ebben az időszakban megvolt a népesség, az etnosz összetartozásának alapja: az azonosságtudat. 895-től a mohácsi vészig tart az ómagyar kor, 1526-tól a középmagyar kor, 1772-től az újmagyar kor 1920-ig. Ez időtől napjainkig már az újabb magyar kor nyelvállapota tartható számon. Ezeknek a korszakoknak külön- 
féle forrásai vannak: a nyelvemlékek, amelyeknek különféle fajairól bőségesen olvashatunk a kötetben az Ibn Ruszta arab földrajzi író által lejegyzett kende és kündü méltóságnevektől a Halotti beszéd és könyörgésen át a 20. századig.

A kötet fö része a 3. fejezet: A magyar nyelv története (99-307.), amelyet nyelvtantörténeti és lexikatörténeti részre osztva tárgyalnak a szerzők. A magyar beszéd hangjainak változását a rekonstruált alapnyelvi állapottól az egyes nyelvtörténeti korszakokon át a mai magyar köznyelvi standardig eljutva írják le. Hasonlóképpen taglalódik a morfématörténet. Az ősmagyar kori egyalakú szótövektől (*hala 'hal') az ómagyar végéig kialakuló különféle többalakú tövekig (út : utat, álom : álmot; néz : nézek; őriz : őrzünk). A toldalékolás elemeinek - a ragoknak, a jeleknek és a képzőknek - létrejötte és maguknak a toldalékoknak a története a névszók és az igék vonatkozásában kap leírást. Itt van megemlítve az ikes ragozás, amely alkalmas a cselekvés tárgyra való irányulását jelezni a tárgy jelölése nélkül: Emberek fa törik (= emberek fát törik). Amikor a $-t$ tárgyrag kialakul, e ragozásmód szerepkörére nincs szükség. A mediális igék mellé nem kívánkozik tárgy: eső esik. Egyes nyelvjárások, így a székely, máig használják az ikes ragozást. Sokan 19. századi nézet szerint szinte máig a kimüvelt, helyes közbeszéd részének tartják, ám kihalása a köznyelvben bizonyosra vehető.

A kézikönyv szófajtörténeti része az alapnyelvi kétféle szerkezetü, egytagú és kéttagú szavak funkciójának bemutatásával kezdődik. Előbbiek rámutató szerepủek, utóbbiak fogalmi tartalmúak lehettek. Bizonyára az indulatszavak a legrégebbiek: Luitprand cremonai püspök Antapodosis címü müvében (959-962 körül) megemlíti eleink húi, húi kiáltozását. Elkülönültek az igei és névszói (ige, melléknév) kategóriák, az ősmagyar korban már van kötőszó, van birtokos névmás és vonatkozó névmás. Az ómagyar kor tovább gazdagítja a szófajokat, kialakulnak a névelők, bizonyos igenevek és névmások.

Természetesen a mondattörténet is része a kézikönyvnek. Először a szószerkezetek, majd az egyszerü és az összetett mondatok kerülnek sorra. A mondattan grammatikai kidolgozottságára alapuló leírásban kevéssé hangsúlyos figyelmeztetés, hogy a különböző korok élőbeszéde voltaképp rekonstrukció. A szövegtörténeti fejezet már külön tárgyalja a beszélt nyelvi szövegeket és az írott nyelvieket, jóllehet az oralitás itt is visszakövetkeztetésen alapul például a ráolvasások, az archaikus népimádságok figyelembevételével is. A kódexek kora írásbeliségének mint fordításirodalomnak vagy mint önállóan fogalmazott magyar szövegnek jellemzői kohézió és koherencia szerint vizsgálható, a szöveg tagolásának, szerkezetének, szövegtípusának tömör vázolása lényegében erről (is) szól. Egy különös szövegfajtára is kitér e fejezet, a szövegamulett bemutatására: „,welee wyselendy” 'magán viseli' valaki a szöveget a Thewrewk-kódexban (1531). Ez manapság is gyakorlat: ruhafeliratok, tetoválások, gépkocsira helyezett szövegek stb. E jelenségek mellett érinti a fejezet az ún. digitális kommunikáció szövegjelenségeit, amelyek az utóbbi években alakultak és alakulnak. 
Az eddigi bő háromezer év alatt a népünk számos más etnikummal és nyelvvel érintkezett, más-más életmód, gazdálkodási rend hatott rá különböző mértékben. A 7. században ős- és óiráni, valamint perzsa szavak mutatják a kereskedelmi kapcsolatokat: ezer, tíz, vám. A 8. századi alán kapcsolatokra biztosan csupán két szó utal: asszony, híd. Jóval több az ótörök jövevényszó (mintegy ötszáz), az oszmán-török hódítás alatti időből körülbelül harminc szó maradt meg máig (papucs, zseb). Szláv eredetre ugyancsak ötszáz körüli szavunk megy vissza, ezek cseh, lengyel, szlovák, szlovén és más nyelvre vallanak. A latin és újlatin szóanyag mennyisége is nagy, hiszen a latin a 10. századtól az egyházi és világi élet szinte minden területén hatott, nem szólva arról, hogy 1844-ig hivatalos államnyelv is volt. A magyar nyelv szóállománya az idők folyamán belső szóteremtéssel is gyarapodott, változott (és változik). Igen nagy az aránya azoknak a szavaknak, amelyek valamely szótőből képző(morfémával) alakulnak. A képzett szó újabb képzővel képzőkkel ellátva nagyon nagy szócsaládokat alkothat, amelyeknek ezért is sokszor szembeötlő magyar jellegük van. A szóképzés mellett a szóösszetétel is szókészlet-gyarapító eljárás, sőt a 18. századtól máig erősödő mértékben (lakcímkártya, pénzmosás, távmunka). Az ilyen módon keletkezett szavak aránya a mai magyarban $80 \%$, ismeretes a jövevényszavak aránya is: $7 \%$. A grammatikai rendszer és a szóállomány együttesen mutatja, hogy minden eddigi (és jelenlegi) hatás mellett meghatározó a magyar jelleg, amelyet az itt nem részletezhetö hangtani vonások is erösítenek.

A szóállomány mennyisége nem mutatja meg azt, hogy egy-egy szónak hány jelentése van, hányféle referenciája, valóságvonatkozása. Az „egyjelentésü” szakszó azt jelenti, hogy közös tartalomra vonatkozik a leggyakoribb köznyelvi változatában. Egyjelentésű egyalakú szavunk alig van, mert a különféle beszédhelyzetekben hamarosan újabb jelentése is kialakul, ez történt például a rádióval. Egyetlen szóalakhoz különböző, elkülöníthető jelentések kapcsolódnak, így van többjelentésü, poliszém szó. A szóalakok jelentéskapcsolatainak viszonyait szemléltető ábra segíti a könyvben.

A tulajdonnevek, a személynevek, a családnevek, a helynevek keletkezése és eredete szintén része a lexikatörténeti áttekintésnek.

A magyar nyelv mindig változatokban élt, ezért a kézikönyv Nyelvváltozat-történet címmel tér ki erre. A nyelvjárások történetéből korszakonkénti leírás olvasható az egyes nyelvi szintek megfelelő jelenségeinek vázolásával. Napjainkban a területi nyelvváltozatok helyett kialakulóban van az ún. regionális köznyelviség, amelyben jórészt fölszámolódott a nyelvjárások hangtani, szóhasználati és grammatikai jellege. Ennek kapcsán kaphat figyelmet magyar köznyelv, a standard alakulástörténete. Az írásbeli és beszélt nyelvi köznyelv a már említett 1844. évi törvény után mutatott látványos fejlődést. A magyar nyelvi korszerüsödés a 19-20. században jól megmutatkozott a szépirodalomban, Vörösmarty, Petőfi, Arany, Jókai, Mikszáth nyelvhasználata és maga az irodalmi nyelv szinte a legutóbbi 
időkig szinte a standardot jelentette, ami természetesen téves fölfogás. Mindenesetre a köznyelvi normának nevezett nyelvhasználat határai évszázadunkban is egyre tágulnak, az argó, a szleng, a vulgarizálódás jól megfigyelhető az „írott beszédnyelviség korának" nyelvében.

A kötet ötödik fejezete a magyar nyelvközösség történetéről szól. Eligazít a honfoglalás korától a magyarság számáról, a körülbelül 300000 magyarral induló népesség (a történelem során nagy ingadozások után) 9981865 föt számlál 2011-ben a mai határokon belül. A 21. század elején a Kárpát-medencei országokra is kiterjedő statisztika szerint mindenütt csökken a magyar népesség, hazánkon kívül hanyatlik a magyar anyanyelvi teljesítőképesség a családias-mindennapi, a közéleti, a szakmai, a tudományos, a publicisztikai és a szépirodalmi területeken is. A magyar nyelvközösség történeti és müvelődéstörténeti áttekintése zárja ezt a fejezetet, amely valóban nem kimondottan nyelvészeti témájú, mégis rendkívül fontos része nemcsak a könyvnek, hanem a nyelvtörténet-folyamat megértésének is. Erre pedig - összhangban a szerkesztők és a szerzők szándékával - különösen „az anyanyelv története iránt érdeklődő minden rendủ és rangú olvasóknak, tehát például a magyartanároknak, a magyar szakos egyetemi és főiskolai hallgatóknak, a tömegtájékoztatás szakembereinek" szükségük van.

A kötet a magyar nyelvtörténetet valóban kézikönyv jellegnek megfelelően és több tekintetben újszerúen mutatja be, utóbbi vonás a nyelvváltozatok kezelésében, a standard alakulástörténetében, a regionális köznyelv és a magyar nyelvközösség történetének leírásában észlelhető. A szakirodalom mérsékelt idézése könnyíti a nem szakember olvasónak a megértést, az új tárgykörü fejezetekben viszont bőségesebb a hivatkozás, ez mindenkinek segíti nem csupán a tájékozódást, hanem az elmélyülést is azokban a nyelvtörténeti jelenségekben, amelyekben valamilyen problémát észlel. Ennél több aligha várható egy szakkönyvtől.

(Kiss Jenö - Pusztai Ferenc szerkesztök: A magyar nyelvtörténet kézikönyve. Budapest: Tinta Könyvkiadó, 2018, 548 o.)

Büky László

nyelvész 


\section{A SZABADSÁGSZERETŐ EMBERNEK}

Mindenki szereti a szabadságot, és mindenki szereti a szabadságszerető embert, Kukorelli Istvánt. Legalábbis ez tűnik ki abból az impozáns kötetből, amely a Gondolat Kiadó gondozásában jelent meg a Tanár Úr 65. születésnapjára. Már a kötet megvalósulásához hozzájáruló intézmények során végigtekintve is megállapíthatjuk, hogy Kukorelli Istvánnak nemcsak a szabadságszerető, hanem a hídember is állandó, eposzi jelzője lehetne. A még érthetőnek tűnő Igazságügyi Minisztérium, az Alkotmánybíróság, az Eötvös Loránd Tudományegyetem jogi kara, a győri Széchenyi István Egyetem jogi kara, és a Károli Gáspár Református Egyetem jogi kara mellett a Bencés Diákszövetség és a Herendi Porcelánmanufaktúra Zrt. is támogatta az ünnepi kötet megjelenését. Még inkább elámulunk, ha megpillantjuk a kötet szerzőinek névsorát. A szerkesztők, Chronowski Nóra, Pozsár-Szentmiklósy Zoltán, Smuk Péter és Szabó Zsolt bizony nagy bravúrt mutatott be a rendkívül színes és szerteágazó anyag rendezésével. Kevesen vannak manapság Kukorelli Istvánon kívül, akik képesek ilyen intézményi és személyi távolságokat hídemberként áthidalni.

Nem mehetünk el szó nélkül a könyv két további furcsasága mellett sem. Az ugyan természetes, hogy az ünnepi kötetben szerepel az ünnepelt arcképe, itt is egy igazán jól sikerült és egészen jellemző fényképet illesztettek az írások elé: a Tanár Úr éppen mosolyogva tanít bennünket a szónoki pulpitus mögül. Az azonban már fejtörést okoz, mit keres a következő lapon dr. Kukorelli István címere, hiszen mindannyian jól tudjuk, szeretett „Kukónk” egyszerü parasztgyerekből lett alkotmánybíró és egyetemi tanár. A nemesség ma már szerencsére nem a vérrel, hanem a tettekkel méretik meg, és ha valaki, akkor Kukorelli István megérdemli a nemesi címert a képzeletbeli, erényekre alapozott társadalmi hierarchiában. Különféle szimbólumok (többek között mérleg és kard) és feliratok (Pax és „Ora et labora”) révén Pécsi L. Dániel próbálta meg egyetlenegy címerben egyesíteni mindazt a sokszínűséget, amelyet a Tanár Úr eddigi életműve jelent. Ha továbblapozunk, minden fejezet előtt Petrás Mária gyönyörü, vallási témájú kerámiáinak fotóira bukkanhatunk. Hálával telve jegyzem meg, hogy egy gyermekét ringató Mária a mi konyhánk falán is ott díszeleg már évek óta a Tanár Úr nászajándékaként.

E rövid recenzió nem léphet fel a teljesség igényével. Elég, ha elhiszik nekünk, hogy a magyar alkotmányjogászok színe-java kivétel nélkül szerepel a tisztelgők sorában. Már az egyes fejezetek címei, amelyek Bibó István $A$ szabadságszeretö ember politikai tízparancsolatából származnak, is sok mindent elárulnak Tanár Úr jelleméröl. Az első így hangzik: „önkényeskedést, akarno- 
koskodást, [...] visszaélést [...] nem tür". Ebben az alkotmányossággal kapcsolatos írásokat találunk, a jogállamiság, a parlamenti demokrácia és a népszavazás témaköreiből. A szerzők közül nem egy tevékenyen részt is vállalt a magyar rendszerváltásban.

A második fejezetet a következő gondolat fémjelzi: „megköveteli magának és megadja másnak a minden embernek kijáró tiszteletet". A kötetnek e terjedelmében is tekintélyes része a jog- és eszmetörténet legkülönbözőbb öszszefüggéseit villantja fel az olvasó számára, a flow elmélettől kiindulva a rule of law-n - és sok más érdekfeszítő témán át - a moralitásig mint módszerig. Egyes tanulmányokban nagy gondolkodók nyomdokán járunk, másutt jelentős történelmi folyamatok, mérföldkőnek számító (jog)intézmények bontakoznak ki a szemünk elött. Mindig a jelen privilégiuma a múltra való visszatekintés képessége - éljünk ezzel a kiváltságunkkal, és lapozzuk fel az ünnepi kötet történeti perspektívájú gyöngyszemeit is bátran! Aktuális kérdések is horogra akadhatnak, miközben a legkülönfélébb témákat felvonultató fejezet írásai között válogatunk.

„Szüntelenül szem előtt tartja, hogy az emberi szabadság és az emberi méltóság egy és oszthatatlan" - mondja a harmadik fejezet fócíme, és valóban: mintha Tanár Úr jellemzése folytatódna e szavakkal. Az alapjogvédelem és az alkotmánybíráskodás kérdései vetődnek fel a számos nagyon is konkrét és aktuális probléma fejtegetése során. Provokatív címek, gondolatébresztő témák ragadják meg az olvasó figyelmét; szép példái annak, hogy az alapjogokhoz hasonló nagy eszmék - amelyek elméletben ma már úgy tartoznak az emberiséghez, mint az egyes emberhez a lélegzetvétel - nem önmagukért, ködös absztrakcióként léteznek, hanem azért, hogy a mindennapi élet leghétköznapibb területein is betöltsék rendeltetésüket.

„Minden közügyben meggyőződése szerint vall színt” - így nyit a negyedik fejezet, amely a demokratikus döntéshozatal, parlamenti jog, kormányzati rendszer kérdéseivel foglalkozik, leginkább hazai viszonylatban. A választási rendszer, az államfő szerepe, valamint a törvényhozás egyes aktuális és történeti vonatkozásai kerülnek ennek során terítékre.

A záró rész nem kisebb súlyú kijelentéssel kezdődik, mint hogy „bízik a közösség erejében”. Hát igen, az a közösség, amelyet az évek hosszú során a Tanár Úr maga köré kovácsolt a legkülönbözőbb világnézetü, politikai beállítottságú és az egymással legádázabban szemben álló focicsapatok drukkereiből álló olyan közösség, amelynek valóban ereje van.

A vaskos kötetet Kukorelli István 1973 és 2016 közötti publikációs tevékenységének áttekintése zárja.

Mindezek után kinek ajánljuk-e kötetet? Mindenkinek, aki szeretne tájékozódni Magyarország közjogi állapotáról, és mindenkinek, aki képes arra, hogy az írott betűk ne csak az eszét, hanem a szívét is megszólítsák. 
(Chronowski Nóra - Pozsár-Szentmiklósy Zoltán - Smuk Péter - Szabó Zsolt szerkesztök: A szabadságszeretö embernek. Liber Amicorum István Kukorelli, Budapest: Gondolat 2017, 901 o.)

Busa Réka doktorandusz, Széchenyi István Egyetem - Deák Ferenc Állam- és Jogtudományi Kar

Deli Gergely egyetemi docens, Széchenyi István Egyetem - Deák Ferenc Állam- és Jogtudományi Kar 